\title{
Controlling plant-parasitic nematodes in sandy soil in the Senegal River Valley using composts based on potentially nematicidal plants
}

\author{
Saïdou Nourou Sall. ${ }^{1}$, Florence Khady Ngom ${ }^{1}$, Sidy Diakhate ${ }^{2}$ \\ 1 Université Gaston Berger, Laboratoire des Sciences Biologiques, Agronomiques et de Modélisation des Systèmes \\ Complexes, BP 234, Saint-Louis, Sénégal; \\ ${ }^{2}$ Green Agro Consulting, Centre de recherche ISRA IRD Bel Air, Route des Hydrocarbures Bâtiment 3, CP 18524, \\ Dakar - Senegal \\ †Corresponding author: saidou-nourou.sall@ugb.edu.sn \\ SALL Saidou Nourou, 'Université Gaston Berger, Laboratoire des Sciences Biologiques, Agronomiques et de \\ Modélisation des Systèmes Complexes, BP 234, Saint-Louis, Sénégal
}

Original submitted in on $18^{\text {th }}$ October 2019. Published online at www.m.elewa.org/journals/ on $31^{\text {st }}$ January 2020

https://doi.org/10.35759/JABs.v145.4

\begin{abstract}
Objective: This study in the Senegal River Basin evaluated the effect of three types of compost, made from manure combined with straw, Calotropis procera (Sodom Apple) or Crotalaria juncea (Indian Hemp), on plant-parasitic as well as free-living nematodes and on the growth of tomato plants.

Methodology and results: This study was performed in a greenhouse where a Mongal tomato was grown during 3 months in a soil that had been abandoned due to infestation by nematodes. The treatments were composts of straw, Calotropis procera Crotalaria juncea and control without compost. The soils amended with compost had significantly higher nematode abundances than the unamended. The compost with Crotalaria juncea gave the highest abundance. The soils with compost also had a much lower proportion of plant-parasitic nematodes than the control soil and much higher proportion of bacterivorous nematodes. The height of the plants was positively correlated with the proportion of bacterivorous nematodes and negatively correlated with the proportion of plant-parasitic nematodes.

Conclusions and application of the results: The influence on the soil nematode community of compost materials is associated more with their phenol content than the total organic carbon. The Calotropis procera and Crotalaria juncea encourage the growth of the bacterivorous nematode community, which plays an important role in maintaining soil fertility, and the growth of omnivorous and predatory nematodes while limiting the growth of the plant-parasitic nematode community. The results suggested that the compost with Crotalaria juncea seems to be worthwhile pursuing as it maintained the equilibrium between nematode feeding guilds while suppressing plant-parasitic nematodes.

Keywords: Compost, Crotalaria, Calotropis, Straw, Nematode, sandy soil.
\end{abstract}




\section{INTRODUCTION}

Farming in the Senegal River Valley is dominated by smallholders where market gardening provides a major part of household revenues (David-Benz, 2002). The yield from these crops is limited by many constraints, such as the damage caused by plant-parasitic nematodes (Chabrier, 2014). These nematodes are proliferating very fast in this region of Senegal due to ideal conditions for multiplication: sandy soils, high temperatures, and traditional crop sequences including vulnerable plants (Chaibou \& Kâ, 2012; Chabrier, 2014). The crops that are most affected are members of the Solanaceae (such as tomatoes, chili peppers, and bell peppers) and the Cucurbitaceae (such as watermelons, zucchini, and melons) where the losses caused by nematodes are estimated to be over $60 \%$ (Haougui et al., 2013a). Local farmers usually resort to chemical treatments, such as bromomethane (methyl bromide), ethoprophos (ethoprop), or carbofuran (Furadan) to control plant-parasitic nematodes. These chemicals present a high risk for human health and the environment while providing only limited, shortterm control over plant-parasitic nematode infestations. Increasingly, alternative ecological methods, based on the relationships between nematodes and their environment, are being investigated, such as applying crop residues, manure, or nematicidal plant residues (Oka, 2010; Hussain et al., 2011). Some studies have shown that organic amendments can control plantparasitic nematodes (Tabarant, 2011). Currently, several plant species are grown in various ways to protect susceptible crops from plant-parasitic nematodes. These plants may be intercropped with vegetable crops, used as green manure, provide crop residues or for soil amendment, or grown in

\section{MATERIALS AND METHODS}

The soil: The soil used for the experiment was collected in 2016 from the agricultural studies farm at $16^{\circ} 03^{\prime} \mathrm{N}, 16^{\circ} 25^{\prime} \mathrm{W}$, in the rural community of Gandon, Saint-Louis Department, Senegal. This farm is run by the Saint Louis Gaston Berger University. The climate is between sub-Canarian and Sahelian with a short rainy season (July to September) and a long dry rotation (Bertrand et al., 2001; L'Etang, 2012). Some plants, such as Crotalaria juncea (Indian hemp) are useful not only as a nematicidal green manure but also for fixing nitrogen as it is a legume (Jourand et al., 2004). Calotropis procera (Sodom apple) is a member of the Asclepiadoideae (milkweed) subfamily and several studies have shown that its leaves affect the activity of plantparasitic nematodes (Ahmed et al., 1996; Tariq et al., 2018). It has been stated that organic amendments become richer in minerals, free of pathogens and weed seeds, and more stable if they are composted before application (Francou, 2003) and most of the literature concerns the effects of composted material on plant-parasitic nematodes (Oka, 2010; Tabarant, 2011). However, there have been very few studies of the entire population of soil nematodes, both free-living and parasitic (Diakhaté et al., 2013) and there have been almost no investigation of nematodes in the sandy soils of the Senegal River Valley. Although plant-parasitic nematodes are the best known, the majority of soil nematodes are free-living and beneficial for soil health and plant growth (Djigal et al., 2012). They mainly feed on bacteria, fungi, protozoans, and other nematodes and they play an important role in soil biological functioning (Bélair, 2005; Villenave et al., 2013). These free-living nematodes are particularly involved making nutrients available in the soil (Ferris, 2010; Villenave et al., 2013). Only about $10 \%$ of nematodes are parasites on plants and animals (Diakhaté, 2014). We evaluated the effect of three types of compost, made from manure combined with straw, Calotropis procera or Crotalaria juncea, on plant-parasitic as well as free-living nematodes and on the growth of tomato plants.

season (October to June). The vegetation is typical of Sahelian shrub-steppe, comprising Acacia raddiana (Vachellia tortilis subsp. raddiana, umbrella thorn acacia), Balanites aegyptiaca (desert date or soapberry tree), Prosopis juliflora (mesquite), Euphorbia balsamifera (balsam spurge or sweet tabaiba), and Calotropis procera (Sodom apple). The soil was taken 
from plots that had been abandoned due to infestation by nematodes (215 individuals per $100 \mathrm{~g}$ soil) comprising $31 \%$ bacterivorous, $1 \%$ fungivorous, $43 \%$ omnivorous and predatory, and $25 \%$ plant-parasitic nematodes. The most recent crop had been chili pepper. Several samples were taken from the $0-20 \mathrm{~cm}$ topsoil layer, combined and sieved to $2 \mathrm{~mm}$. Table 1 lists the physical and chemical properties of the topsoil determined by LAMA/IRD, Centre ISRA/IRD Bel Air, Dakar.

Table 1. Soil properties for the $0-20 \mathrm{~cm}$ topsoil layer (Mean \pm SE)

\begin{tabular}{cc}
\hline $\mathrm{pH}$ & $6,7 \pm 0.2$ \\
$\mathrm{CE}$ & $61.3 \pm 3.5 \mu \mathrm{S} / \mathrm{cm}$ \\
\hline Particle sizes & \\
Clay & Fraction $(\%)$ \\
Silt & $3.3 \pm 0.4$ \\
Sand & $3.0 \pm 0.6$ \\
Nutrients & $93.5 \pm 0.3$ \\
N organic & Concentration \\
C organic & $0.16 \pm 0.04 \mathrm{~g} / \mathrm{kg}$ \\
P total & $1.83 \pm 0.3 \mathrm{~g} / \mathrm{kg}$ \\
P available & $34.9 \pm 9.0 \mathrm{mg} / \mathrm{kg}$ \\
Exchangeable bases & $4.88 \pm 0.7 \mathrm{mg} / \mathrm{kg}$ \\
Ca & $(\%)$ \\
Mg & $1.1 \pm 0.1$ \\
Na & $0.6 \pm 0.1$ \\
$\mathrm{~K}$ & $0.1 \pm 0.1$ \\
\hline CEC & $0.2 \pm 0.01$ \\
\hline Cation exchange capacity & $(\mathrm{meq} / 100 \mathrm{~g})$ \\
\hline
\end{tabular}

The composts: The experiment was carried out using 3 composts ( $\mathrm{C} 1, \mathrm{C} 2$, and $\mathrm{C} 3$ ) obtained by composting selected residues with a base compost for 6 months in a pit. The base compost was a mixture of animal manure, poultry manure, and Leucaena leucocephala (river tamarind) residues.

C1: $40 \%$ straw with $60 \%$ base compost.

C2: $40 \%$ Calotropis procera (Sodom apple) residues with $60 \%$ base compost.

C3: 40\% Crotalaria juncea (Indian hemp) residues with $60 \%$ base compost.

The straw based compost, $\mathrm{C} 1$, was considered to be the standard type of compost commonly used on local farms. The water content was monitored during composting and water was added when necessary to keep the water content close to $50 \%$ dry matter. The temperature was checked regularly.

The experiment: The Mongal tomato variety was used and the seedlings were grown in a nursery for 21 days before planting. After replanting, the buckets were watered with only $400 \mathrm{~mL}$ of water every 3 days to avoid waterlogging and leaching of the compost. The tomatoes were grown in $10 \mathrm{~L}$ buckets, under cover, from August to October 2015. The average temperature in the greenhouse was $34.4^{\circ} \mathrm{C}$ and the average relative humidity was $68.3 \%$. The buckets were filled $2 / 3$ full with about $15 \mathrm{~kg}$ soil. The experimental design was completely randomized with 4 treatments. The four treatments were control without compost (CO), and composts with straw (C1), Calotropis procera (C2), or Crotalaria juncea (C3). $380 \mathrm{~g}$ of compost was applied to each bucket (equivalent to 10 tha in the field). Mineral NPK 9-23-30 was added at a rate of $8 \mathrm{~g}$ per bucket (equivalent of $200 \mathrm{~kg} / \mathrm{ha}$ ) before planting and $8 \mathrm{~g}$ of urea (N $46 \%$ ) per bucket (200 kg/ha) was added 20 days after planting. This was standard farming practice in the region. For each treatment, 5 replicates were done.

Composition of the composts: The soluble fraction (SOL) of the different materials was determined by hot water extraction $\left(100^{\circ} \mathrm{C}\right)$ for $30 \mathrm{~min}$, followed by extraction with neutral detergent $\left(100^{\circ} \mathrm{C}\right)$ for $60 \mathrm{~min}$ (Linères \& Djakovitch, 1993). The hemicellulose (HEM), cellulose (CEL), and lignin (LIG) fractions were then determined (Van Soest et al., 1991). The results are expressed as a percentage of the organic fraction of the 
compost. The total phenol content was determined by extraction in $80 \%$ ethanol and titration with FolinCiocalteu reagent (Boizot \& Charpentier, 2006); the results are expressed as $w / w$ of the dry matter. Total organic $C$ was analysed by the methods of Walkley \& Black (1934) and organic $\mathrm{N}$ by the method of Kjeldahl (Bremner \& Mulvaney, 1982). The composts were analysed by LAMA/IRD, Centre ISRA/IRD Bél Air, Dakar and LNERVIISRA, Hann, Dakar.

Plant growth: At 45 days after replanting, the height of the plants was measured, the buckets were emptied and the root mass was measured after separation, washing and drying in an oven for $80^{\circ} \mathrm{C}$ for $72 \mathrm{~h}$.

Total abundance and nematode trophic groups: The soil was collected and the nematodes were extracted

\section{RESULTS}

Compost characteristics: Table 2 lists the chemical and biochemical characteristics of the composts. The composts were similar but C3 had significantly lower organic carbon (146.2 g/kg DM) and total phenols (35.5 $\mathrm{mg} / \mathrm{kg} \mathrm{DM}$ ) compared to other composts. While among the composts, $\mathrm{C} 1$ had the higher organic N $(19.5 \mathrm{~g} / \mathrm{kg}$ DM).

Effect of the composts on plant growth: The root biomass was higher with $\mathrm{C} 2$, but there were no significant differences between composts (Table 3 ). In addition, for the plant height no significant differences were found between composts, while soils amended with composts showed a tendency of higher height compared to the unamended soil.

Effect of composts on the total nematode abundance: All of the soils amended with composts (C1, C2 and C3) had a significantly higher abundance of nematodes than $\mathrm{CO}$, the control without compost (272 ind / $100 \mathrm{~g}$ soil) (Figure 1). C3 (Crotalaria juncea) had a significantly higher abundance of nematodes (1083 ind / $100 \mathrm{~g}$ soil) than either C1 (straw, 583 individuals per $100 \mathrm{~g}$ of dry soil) or C2 (Calotropis procera, 605 individuals per $100 \mathrm{~g}$ of dry soil). There was no significant difference between $\mathrm{C} 1$ and $\mathrm{C} 2$ (Figure 1).

Effect of composts on total abundance and nematode trophic groups: Before we started the experiment, the soil from the farm had a fairly balanced nematode population with $31 \%$ bacterivorous 187 individuals $/ 100$ dry soil, $1 \%$ fungivorous (5 individuals/100dry soil), $43 \%$ omnivorous and predatory (233 individuals/100dry soil), and $25 \%$ plant-parasitic nematodes (132 individuals/100dry soil). For the control treatment $\mathrm{CO}$, the proportion of plant-parasitic from $250 \mathrm{~g}$ of wet soil using a Seinhorst elutriator (Seinhorst, 1962). The nematodes were counted at 40X magnification using a dissecting microscope before being fixed in a formaldehyde-glycerol mixture. Representative sub-samples mounted on mass slides were used for identification of the trophic groups (400X).

Statistics: XLSAT (version 2016.05.34217) was used for the statistical analyses. ANOVA was used to evaluate the effects of each treatment. Fisher tests were used to determine significance at $P<0.05$. A correlation matrix was drawn up for the organic carbon and nitrogen content, the height and dry root mass of the plants, and the abundance and feeding guild structure of the nematodes.

nematodes increased from 25\% (132individuals/100dry soil) to $82 \%$ (555 individuals/100dry soil). For the other treatments, the proportion of bacterivorous nematodes was 36 percentage points (pp) (C1), $34 \mathrm{pp}$ (C2), and 13 $\mathrm{pp}(\mathrm{C} 3)$ higher than for $\mathrm{C} 0$ and the proportion of plantparasitic nematodes was $33 \mathrm{pp}(\mathrm{C} 1), 51 \mathrm{pp}(\mathrm{C} 2)$, and $50 \mathrm{pp}$ (C3) lower than for $\mathrm{CO}$ (Figure 2). For the standard compost $\mathrm{C} 1$, The population was evenly divided between plant-parasitic nematodes $(51 \%)$ with 710 individuals/100dry soil and bacterivorous nematodes with 474 individuals/100dry soil $(49 \%)$ and no omnivorous, predatory, or fungivorous nematodes were found in that treatment. The abundance of fungivorous nematodes was very low in our treatments (Figure 2).

Correlations between compost organic $\mathrm{C}$ and $\mathrm{N}$, nematode populations, and plant growth: There were a number of significant correlations $(P<0.05)$. The proportion of bacterivorous nematodes was positively correlated with organic carbon $(r=0.983)$ and organic nitrogen $(r=0.937)$ (Table 4). The proportion of plant-parasitic nematodes was negatively correlated with organic carbon $(r=-0.965)$ and organic nitrogen $(r$ $=-0.914$ ). Adding compost increases the proportion of bacterivorous nematodes while reducing the proportion of plant-parasitic nematodes - these two feeding groups were negatively correlated $(r=-0.913)$. The height of the plants was positively correlated with the proportion of bacterivorous nematodes $(r=0.806)$ and negatively correlated with the proportion of plantparasitic nematodes $(r=-0.900)$. The proportion of omnivorous and predatory nematodes was positively correlated with the total abundance $(r=0.889)$. 
Table 2. Chemical and biochemical characteristics of the composts (Mean $\pm \mathrm{SE}$ )

\begin{tabular}{cccc}
\hline Characteristic & C1† & C2 & C3 \\
\hline Ash (\% DM) & $61.6 \pm 5.2 \mathrm{a}$ & $61.9 \pm 3.5 \mathrm{a}$ & $69.3 \pm 1.8 \mathrm{~b}$ \\
Organic fraction (\% DM) & $38.4 \pm 5.2 \mathrm{a}$ & $38.1 \pm 3.5 \mathrm{a}$ & $30.7 \pm 1.8 \mathrm{~b}$ \\
Soluble fraction (\% OF) & $35.5 \pm 3.1 \mathrm{a}$ & $36.2 \pm 8.8 \mathrm{a}$ & $36.7 \pm 6.3 \mathrm{a}$ \\
Hemicellulose (\% OF) & $23.5 \pm 1.0 \mathrm{a}$ & $24.9 \pm 2.5 \mathrm{a}$ & $22.9 \pm 1.8 \mathrm{a}$ \\
Cellulose (\% OF) & $21.3 \pm 1.4 \mathrm{a}$ & $21.0 \pm 3.0 \mathrm{a}$ & $21.9 \pm 2.1 \mathrm{a}$ \\
Lignin (\% OF) & $19.6 \pm 0.8 \mathrm{a}$ & $17.8 \pm 3.6 \mathrm{a}$ & $18.4 \pm 2.6 \mathrm{a}$ \\
Total phenols (mg/kg DM) & $67.1 \pm 14.6 \mathrm{a}$ & $92.9 \pm 19.4 \mathrm{a}$ & $35.6 \pm 19.9 \mathrm{~b}$ \\
C organic (g/kg DM) & $187.1 \pm 32.0 \mathrm{a}$ & $182.2 \pm 11.7 \mathrm{a}$ & $146.2 \pm 8.8 \mathrm{~b}$ \\
N organic (g/kg DM) & $19.5 \pm 1.7 \mathrm{a}$ & $15.0 \pm 1.6 \mathrm{~b}$ & $16.3 \pm 0.8 \mathrm{~b}$ \\
\hline
\end{tabular}

$\dagger$ C1: standard manure + straw, C2: manure + Calotropis procera, C3: manure + Crotalaria juncea.

$\ddagger$ Values on the same line followed by different letters are significantly different $(P<0.05)$.

Table 3. Plant height and root biomass with the various composts

\begin{tabular}{ccc}
\hline Treatment & Height $(\mathbf{c m})$ & Root biomass $\mathbf{( g )}$ \\
\hline C0 $†$ & $45.8 \pm 22.8 \mathrm{a} \ddagger$ & $2.2 \pm 2.3 \mathrm{a}$ \\
C1 & $71.8 \pm 11.9 \mathrm{a}$ & $2.1 \pm 1.0 \mathrm{a}$ \\
C2 & $78.8 \pm 19.8 \mathrm{a}$ & $4.6 \pm 2.9 \mathrm{a}$ \\
C3 & $62.5 \pm 15.7 \mathrm{a}$ & $2.6 \pm 0.5 \mathrm{a}$ \\
\hline
\end{tabular}

†C0: no compost, C1: standard manure + straw, C2: manure + Calotropis procera, C3: manure + Crotalaria juncea.

$\ddagger$ Values in the same column followed by different letters are significantly different $(P<0.05)$.

Table 4. Pearson correlation matrix for compost organic $\mathrm{C}$ and $\mathrm{N}$, nematode populations, and plant growth

\begin{tabular}{|c|c|c|c|c|c|c|c|c|c|}
\hline & $\begin{array}{c}\text { C } \\
\text { organic }\end{array}$ & $\begin{array}{c}\mathrm{N} \\
\text { organic }\end{array}$ & $\begin{array}{l}\text { Plant } \\
\text { height }\end{array}$ & $\begin{array}{c}\text { Root } \\
\text { biomass }\end{array}$ & $\begin{array}{l}\text { Total } \\
\text { abund. }\end{array}$ & $\begin{array}{l}\text { Bacteri- } \\
\text { vorous }\end{array}$ & $\begin{array}{l}\text { Fungi- } \\
\text { vorous }\end{array}$ & $\begin{array}{c}\text { Omni. }+ \\
\text { predatory }\end{array}$ & $\begin{array}{c}\text { Plant } \\
\text { parasitic }\end{array}$ \\
\hline C organic & 1.000 & & & & & & & & \\
\hline $\mathrm{N}$ organic & $0.970 \dagger$ & 1.000 & & & & & & & \\
\hline Plant height & 0.826 & 0.675 & 1.000 & & & & & & \\
\hline Root biomass & 0.419 & 0.204 & 0.858 & 1.000 & & & & & \\
\hline Total abundance & 0.566 & 0.675 & 0.349 & 0.047 & 1.000 & & & & \\
\hline Bacterivorous & 0.983 & 0.937 & 0.806 & 0.403 & 0.413 & 1.000 & & & \\
\hline Fungivorous & 0.329 & 0.210 & 0.695 & 0.820 & 0.486 & 0.212 & 1.000 & & \\
\hline Omnivorous+predatory & 0.205 & 0.290 & 0.188 & 0.117 & 0.889 & 0.023 & 0.653 & 1.000 & \\
\hline Plant parasitic & -0.965 & -0.914 & -0.900 & -0.571 & -0.657 & -0.913 & -0.563 & -0.388 & 1.000 \\
\hline
\end{tabular}

. $\nmid$ r values in bold are significant at $P<0.05$. 


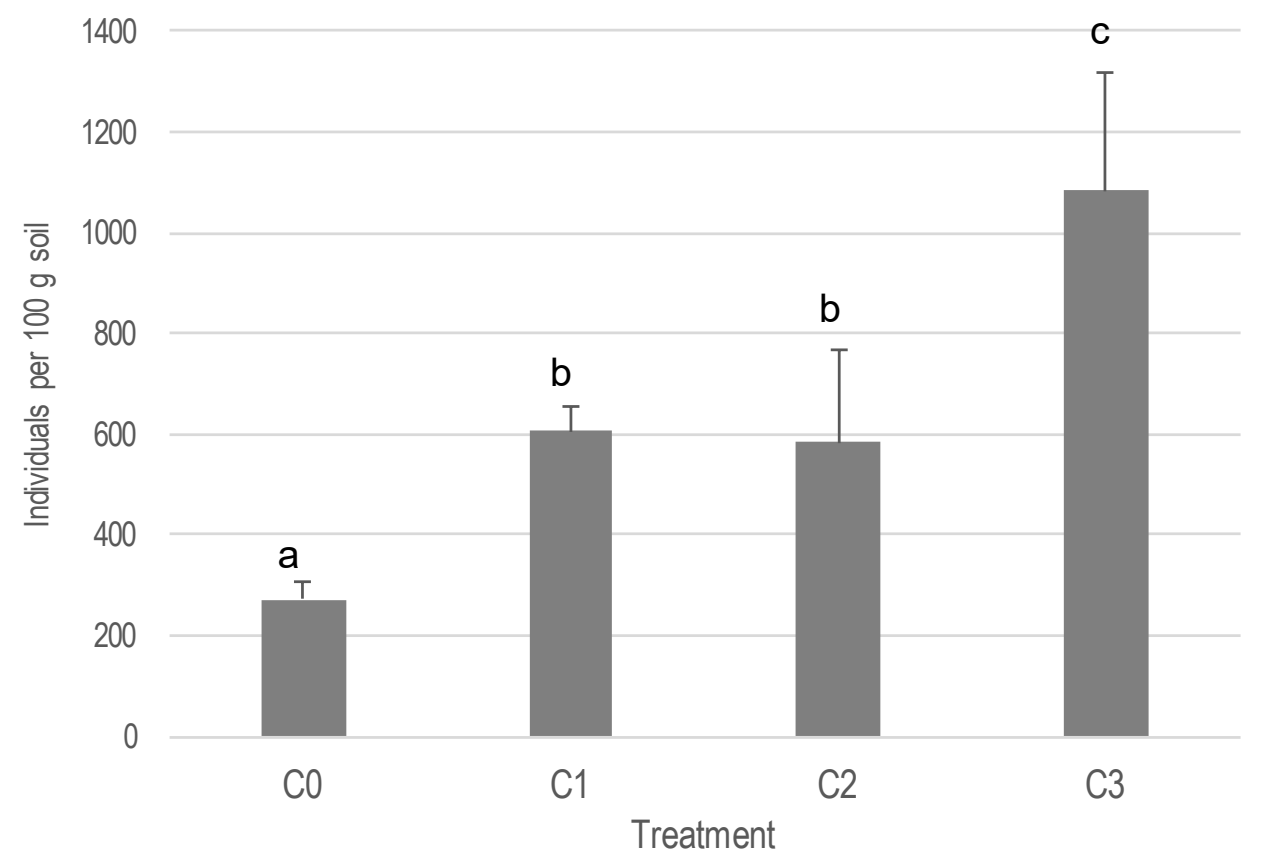

Figure 1: Total abundance of nematodes for the various treatments. (C0: no compost, $\mathrm{C} 1$ : standard manure + straw, C2: manure + Calotropis procera, C3: manure + Crotalaria juncea). Abundances with different letters are significantly different $(P<0.05)$.

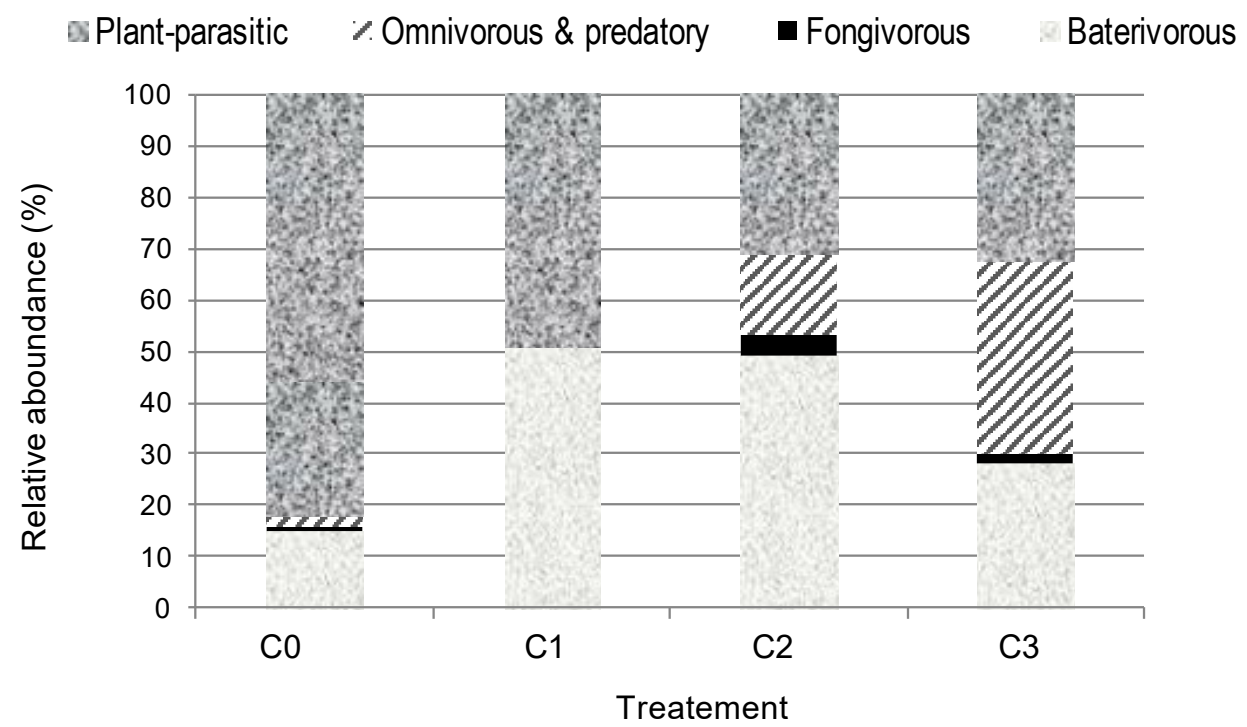

Figure 2: Effect of the composts on the nematode feeding guild structure ( $\mathrm{C} 0$ : no compost, $\mathrm{C} 1$ : standard manure + straw, C2: manure + Calotropis procera, C3: manure + Crotalaria juncea).

\section{DISCUSSION}

Effect of the composition of the composts on the nematode populations: The soils with added compost (C1, C2, and C3) had significantly higher nematode abundances than the control soil without compost (C0). This higher abundance is probably related to the increased availability of organic matter encouraging microbial activity and, consequently, the proliferation of bacterivorous nematodes (Neher, 2010). The compost with Crotalaria juncea (C3) recorded the highest nematode abundance in this study which may be explained by the lower phenol content in this compost. Similar results were obtained in natural conditions in an 
agroforestry system in Senegal (Diakhaté et al., 2013). The soils cultivated with compost had significantly lower proportion of plant-parasitic nematodes than the soil cultivated without compost (C0): 33 percentage points lower for C1, $51 \mathrm{pp}$ lower for C2, and $50 \mathrm{pp}$ lower for C3. Several studies have stated that the influence on the soil nematode community of organic materials is associated with their chemical composition, and so is its efficacy of controlling plant parasitic nematodes ( $\mathrm{Li}$ et al., 2018; Tariq et al., 2018). Other studies have shown the effects of phenols on the relationship between nematodes and their biological controls (Duponnois et al., 2001; Chapuis-Lardy et al., 2015; Oliveira et al., 2019). The reduction in plant-parasitic nematodes with the addition of compost could also be explained by changes in the physical and biological properties of the soil making it less favourable for plant-parasitic nematode growth (Oka, 2010) confirming that ecological control is a valid approach (Cadet et al., 2005). Other factors may help to control plant-parasitic nematodes. This study analysis of the proportions of the various feeding groups showed the importance of the interactions between these groups. For all treatments with compost, the proportions of bacterivorous nematodes were higher and the proportions of plant-parasitic nematodes were lower than the control. Adding compost stimulates a rapid growth of bacterial population (Sall et al., 2003) and, consequently, the abundance of bacterivorous nematodes which depends on the accessibility of bacteria (Villenave et al., 2013). This in turn, improves plant growth. This study showed a positive correlation between the proportion of bacterivorous nematodes and organic carbon content $(r=0.983, P<0.05)$, between the proportion of bacterivorous nematodes and plant height $(r=0.806, P<0.05)$ and a similar correlation between the organic carbon content and the height of the plants $(r=0.826, P<0.05)$. Plantparasitic nematodes often affect yields (Tabarant, 2011; Djigal et al., 2012) and this was confirmed by the negative correlation between the proportion of plantparasitic nematodes and the plant height $(r=-0.9 ; P<$ 0.05). Our study suggested that the organic carbon content is not a useful indicator of the reduction of plant-parasitic nematodes, even though there was a negative correlation $(r=-0.965 ; P<0.05)$ with the proportion of plant-parasitic nematodes. The organic carbon contents of treatments $\mathrm{C} 1$ (compost with straw) and C2 (compost with C. procera) were significantly higher than that of treatment C3 (compost with C. juncea) but C2 had more plant-parasitic nematodes.
Omnivorous and predatory nematodes were included as a group in this study as they are not only at the top of the soil food web, but they also have very similar functions (Ferris, 2010; Villenave et al., 2013). For the soils with composts incorporating Calotropis procera (C2) and Crotalaire juncea (C3), the reduction by about 50 percentage points in the proportion of plant-parasitic nematodes, compared to the soil without compost (C0), was associated with a large increase in the proportion of omnivorous and predatory nematodes. This could indicate top-down regulation of the plant-parasitic nematodes through predation by the omnivorous and predatory nematodes (Djigal et al., 2012; Diakhaté et al., 2013). The abundance of omnivores and predators is often used as an indicator of a presence of a complex food web with several types of interaction (Villenave et al., 2013) and the omnivores and predators at a higher trophic level can regulate the equilibrium between the nematode feeding guilds (Djigal et al.2012). Ultimately, the compost with Crotalaria juncea (C3) seems to be worthwhile pursuing as it maintained the equilibrium between nematode feeding guilds while suppressing plant-parasitic nematodes.

Effect of the type of compost on plant growth parameters: Although the compost with Calotropis procera (C2) result in the highest root biomass, the effect of the compost quality on plant growth were not significant in this study. This could be a result of similarity of the biochemical composition of the three composts: the results of the Van Soest fibre analysis were not significantly different. Another study found better growth with poultry manure than with goat, sheep or cattle manure (Haougui et al., 2013b). These manures have different biochemical properties. However, it noteworthy that there were also no significant differences between $\mathrm{CO}$ and the other treatments. Similar results were found by ChapuisLardy et al. (2015) when adding Piliostigma reticulatum residues to millet (Chapuis-Lardy et al., 2015). These authors also found that adding the residues had an effect on nematodes but, at the same time, had no significant effect on the millet growth parameters. This discrepancy could be explained by the phenol and lignin compounds that are known to prevent organic $\mathrm{N}$ mineralization in the early stage of residue decomposition (Palm and Sanchez 1991, Sall et al., 2003). These authors showed that mineral $N$ could be available for plant uptake at later stage, however, the duration of our experiment ( 45 days) might have been too short to allow this effect to be seen. 


\section{CONCLUSION}

As part of the search for a valuable approach for developing nematicidal composts based on local resources, our study has shown that composts based on local vegetation such as Calotropis procera and particularly Crotalaria juncea encourage the growth of the bacterivorous nematode community, which plays an important role in maintaining soil fertility, and the growth

\section{ACKNOWLEDGEMENTS}

The authors would like to thank Sidy Sidibé and François Diouf for their help with preparing and running the experiment and the technicians of the LAMA and LEMSAT for their help with the analyses. The authors are grateful to Tony Tebby for revising the English version and correcting the manuscript. The work was

\section{REFERENCES}

Ahmed R, Shahab MZ, Inam-Ui-Haq M, Javed N, Dogar MA, Khan MY, 1996. Effect of soil amendment with Calotropis procera for the control of Meloidogyne javanica infection on eggplant. Pakistan Journal of Nematology, 14 (1): 55-59.

Bélair G 2005. Les nématodes, ces anguillules qui font suer les plantes par la racine. Phytoprotection 86: 65-69.

Bertrand C, Lizot J, Mazollier C, 2001. Lutter contre les nématodes à galles en Agriculture Biologique. Rev.: GRAB AVINON, France, pp. 25-29.

Boizot N, Charpentier JP, 2006. Méthode rapide d'évaluation du contenu en composés phénoliques des organes d'un arbre forestier. Cah. Tech. INRAN. N ${ }^{\circ}$ special. pp 79-82.

Bremner JM, Mulvaney CS, 1982. Nitrogen total. In: Page AL Miller RH Keeney DR (Eds.), Methods of Soil Analysis, Part 2. Chemical and Microbiological Properties. American Society of Agronomy, Madison, pp. 595-624.

Cadet P, Masse D, Thioulouse J, 2005. Relationships between plant-parasitic nematode community, fallow duration and soil factors in the SudanoSahelian area of Senegal. Agriculture, Ecosystems and Environment, 108: 302-317.

Chabrier C, 2014. Solution de lutte contre les nématodes au Sénégal. Rapport de mission au Sénégal du 26 janvier au 6 février 2014, $50 p$.

Chaibou LI, Kâ B, 2012. Compétitivité du secteur agricole: Cas du Sénégal. Groupe de travail, Centre d'Etudes de Politiques pour le of omnivorous and predatory nematodes while limiting the growth of the plant-parasitic nematode community. These preliminary results are focused on the whole nematode community with a single fixed dose of compost. Further study is needed to evaluate the effects of different doses of compost on various plantparasitic nematode taxa.

supported by the PERMIS project founded by the FIRST/MESRI of Senegal (Fonds d'Impulsion pour la Recherche Scientifique et Technique du Ministère de l'Enseignement Supérieur, de la Recherche et de I'Innovation).

Développement, Ministère de l'Economie et des finances, 90p.

Chapuis-Lardy L, Diakhaté S, Djigal D, Ba AO, Masse D, Sembene PM, 2015. Nematicidal effect of Piliostigma reticulatum against plant parasitic nematode Helicotylenchus dihystera. Journal of Nematology, 47 (3): 214-217.

David-Benz H, 2002. "Rapport d'activités de fin de contrat d'assistance technique". PSI/CORAF, Saint Louis. Sénégal $54 p$

Diakhaté S, Villenave C, Diallo $\mathrm{NH}, \mathrm{Ba} A O$, Djigal D, Masse D, Sembene PM, Chapuis-Lardy L, 2013. The influence of a shrub-based intercropping system on the soil nematofauna when growing millet in Senegal. J. Soil Biol. 57: $37-41$.

Diakhaté S, 2014. Influence de l'arbuste Piliostigma reticulatum (D.C.) Hochst (Caesalpinioideae) sur les communautés de microorganismes et de nématodes d'un sol cultivé en mil au Sénégal (Nioro), Thèse de Doctorat, Université Cheikh Anta Diop, Dakar, 142p.

Djigal D, Chabrier $C$, Duyck PF, Achard R, Quénéhervé $\mathrm{P}$, Tixier $\mathrm{P}, 2012$. Cover crops alter the soil nematode food web in banana agroecosystems. Soil Biol. Biochem. 48:142150.

Duponnois R, Chotte JL, Sall SN, Cadet P, 2001. The effects of organic amendments on the interactions between a nematophagous fungus Arthrobotrys oligospora and the root-knot nematode Meloidogyne mayaguensis 
parasitizing tomato plants. Biology and Fertility of Soils 34: 1-6.

Ferris $H, 2010$. Contribution of nematodes to the structure and function of the soil food web. $J$. Nematol. 42: 63-67.

Francou C, 2003. Stabilisation de la matière organique au cours du compostage de déchets urbains: influence de la nature des déchets et du procédé de compostage - recherche d'indicateurs pertinents. Thèse de Doctorat, Institut National Agronomique Paris-Grignon, 291p.

Haougui $\mathrm{A}$, Ghazali $\mathrm{Cl}$, Nouri $\mathrm{KM}$, Assoumane $\mathrm{M}$, Karimou I, Delmas P, 2013a. Comment lutter contre les nématodes parasites des cultures maraichères par la solarisation? Fiche Technique, Institut National de la Recherche Agronomique du Niger (INRAN) $5 p$.

Haougui A, Toufique M, Sinaba F, Doumma A, Adam T, 2013b. Effet de quatre types de fumiers d'animaux domestiques sur le développement de Meloidogyne javanica et la croissance du poivron (Capsicum annuum) sous serre, Journal of Applied Biosciences 67: 5228 5235.

Hussain MA, Tariq M, Kayani MZ, 2011. Efficacy evaluation of azadirachta indica, calotropis procera Datura stramonium and tagetes erecta against root-knot Nematodes meloidogyne incognita, Pakistan Journal of Botanical, 43: 197-204.

Jourand P, Rapior S, Fargette M, Mateille T, 2004. Nematostatic effects of a leaf extract from Crotalaria virgulata subsp. grantiana on Meloidogyne incognita and its use to protect tomato roots. Nematology, Volume 6, Issue 1 , pages $79-84$.

L'Etang, 2012. Effet de différents paramètres de l'environnement sur le déterminisme biochimique d'exsudats racinaires de Crotalaria spp.: Application à la nématorégulation en production végétale, Thèse de Doctorat, Université des Antilles et de la Guyane, 165p.

Li J, Wang D, Fan W, He R, Wu J, 2018. Comparative effects of different organic materials on nematode community in continuous soybean monoculture soil. Applied Soil Ecology, 125: 12-17.

Linères M, Djackovitch JL, 1993. Caracté risation de la stabilite biologique des apports organiques par l'analyse biochimique. p. 159-168. In J. Decroux and J.C. Ignazi (ed.) Matières organiques et agricultures. Quatrième journées de l'analyse de terre et cinquième forum de la fertilisation raisonnée. GEMASCOMIFER, Paris.

Neher DA, 2010. Ecology of plant and free-living nematodes in natural and agricultural soil. Annu. Rev. Phytopathol. 48:371-394.

Oka Y, 2010. Mechanisms of nematode suppression by organic soil amendments. Applied Soil Ecology, Vol.44, Issue 2, Nematology, Unit, Gilat Research Center, M.P. Negev 85280, Israel, pp 101-115.

Oliveira DF, Costa VA, Terra WC, Campos VP, Martins SJ, 2019. Impact of phenolic compounds on Meloidogyne incognita in vitro and in tomato plants. Experimental Parasitology, 199: 17-23. https://doi.org/10.1016/j.exppara.2019.02.009

Palm CA, Sanchez PA, 1991. Nitrogen release from leaves of some tropical legumes as affected by their lignin and polyphenolic contents. Soil Biol Biochem 23:83-88

Sall SN, Masse D, Bernard-Reversat F, Guisse A, Chotte JL, 2003. Microbial activities during the early stage of laboratory decomposition of tropical leaf litters: the effect of interactions between litter quality and exogenous inorganic nitrogen. Biology and Fertility of Soils 39: 103111.

Seinhorst JW, 1962. Modifications of the elutriation method for extracting nematodes from soil. Nematologica, 8: 117-128.

Tabarant P, 2011. Effets d'apport de matières organiques sur le contrôle biologique des nématodes parasites du bananier en Guadeloupe. Thèse de doctorat, L'Institut des Sciences et Industries du Vivant et de l'Environnement, 176p.

Tariq M, Khan A, Asif M, Khan F, Ansari T, Siddiqui MA, 2018. Nematode suppressive effect of botanicals against the root-knot nematode $M$. Incognita infesting Solanum melongena L. Trends in Biosciences, p. 2570

Van Soest PJ, Robertson JB, Lewis BA, 1991. Symposium: carbohydrate methodology, metabolism, and nutritional implications in dairy cattle. Methods for dietary fibre, neutral detergent fibre, and nonstarch polysaccharides in relation to animal nutrition. Journal of Dairy Science 74, 3583-3597. 
Villenave C, Coll P, Le Cadre E, Mérot A, 2013. La caractérisation du fonctionnement biologique $\mathrm{du}$ sol en viticulture biologique peut être réalisée par l'analyse de la nématofaune. Innovations Agronomiques 32: 391-400.
Walkley A, Black IA 1934. An examination of the Degtjareff method for determining soil organic matter and a proposed modification of the chromic acid titration method. Soil Science 37: 29-38. 